\title{
Dietary fibre and available carbohydrates in Finnish vegetables and fruits
}

\author{
PERTTI VARO, RAILI LAINE, KIRSTI VEIJALAINEN, AILA ESPO, \\ ANNE WETTERHOFF and PEKKA KOIVISTOINEN \\ Department of Food Chemistry and Technology, University of Helsinki, \\ SF-00710 HELSINKI 71, Finland
}

\begin{abstract}
The dietary fibre and available carbohydrate contents of vegetables, fruits and berries commonly consumed in Finland were analysed using the Englyst total carbohydrate method. The tables give the composition of 73 fresh and processed vegetables and fruits. The estimated average daily intakes of carbohydrates received from this category of foods were: total soluble sugars $23.7 \mathrm{~g}$, starch $30.6 \mathrm{~g}$ and dietary fibre $7.2 \mathrm{~g}$ (energy level $10 \mathrm{MJ}$ ).
\end{abstract}

\section{Introduction}

Vegetables and fruits are the main sources of dietary fibre after cereal products. A considerable portion of vegetable and fruit fibre is water soluble. Consequently, its physical properties are different from those of cereal fibre; its waterbinding capacity is especially high (EASTwOOD 1983). Some fruit and berry products contain added sugar, but on the whole, natural sugars occur in greater amounts in this category of foods. The starch content is generally low, except in potato, which is one of the main sources of starch in Finland.

In the present study the dietary fibre and available carbohydrates in the vegetable foods commonly consumed in Finland were analysed in an attempt to establish in detail the carbohydrate composition of Finnish foods (VARO et al. 1984). The foods were analysed according to the method of ENGLYST (1981).

\section{Material and methods}

The sample material, $2-4$ subsamples (1.5 $-2 \mathrm{~kg}$ each) per item, was bought from local retail shops. Subsamples were washed and cut as in common household practice into edible portions, which were then united as one sample proper. Part of this was freezedried and homogenized in a blender. Only one sample per item was analysed. This is a 


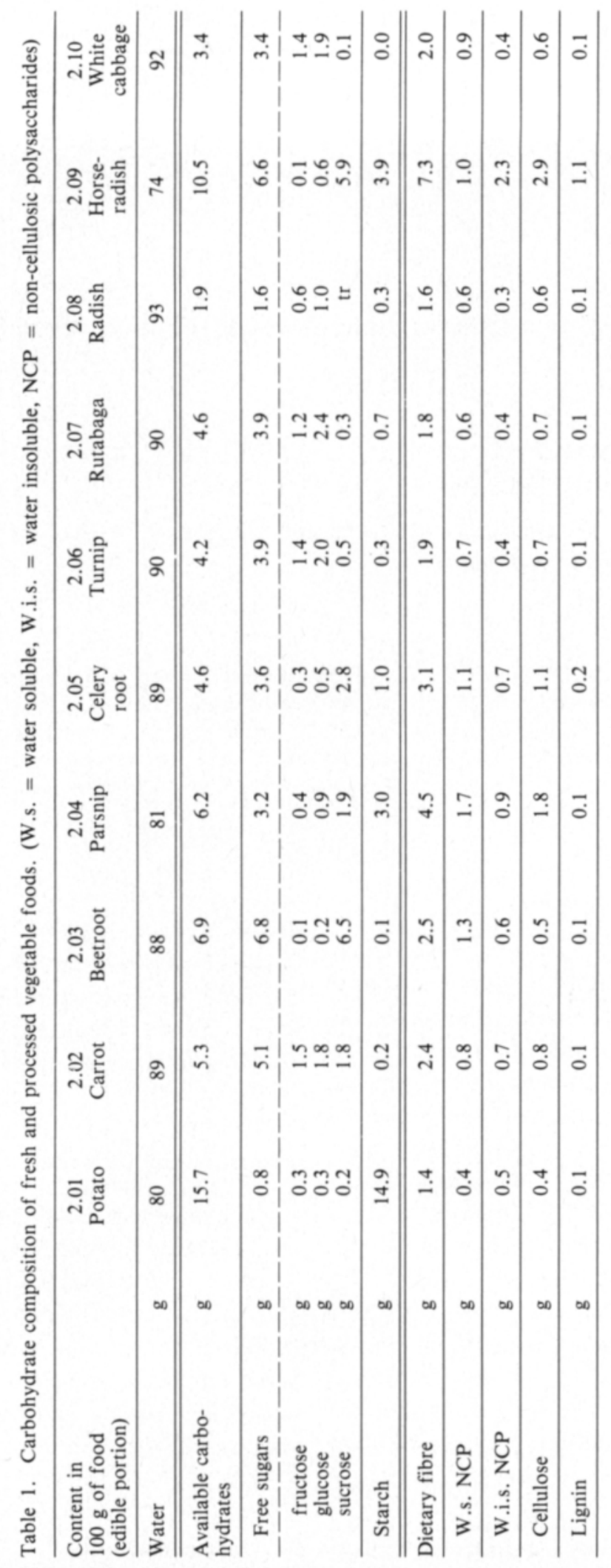




$$
\begin{aligned}
& \text { | }
\end{aligned}
$$

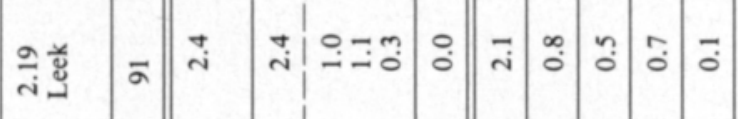

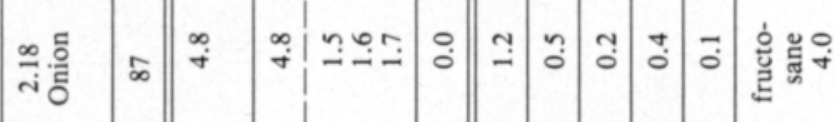

$$
\begin{aligned}
& \text { ב⿱艹 }
\end{aligned}
$$

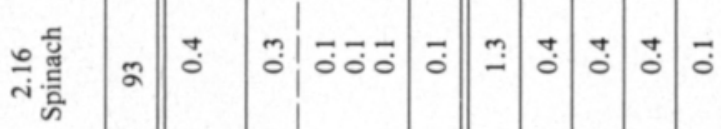

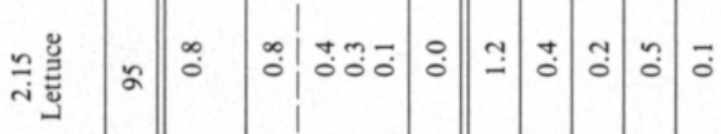

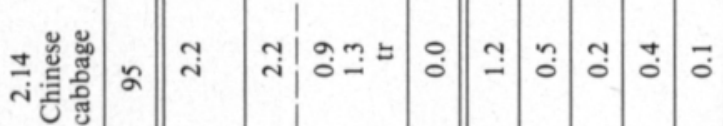

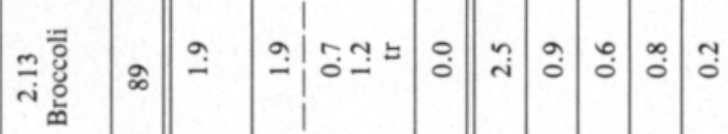

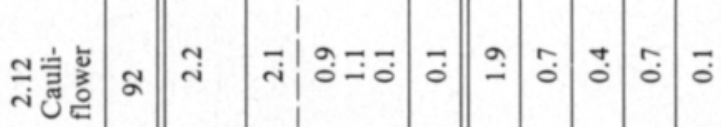

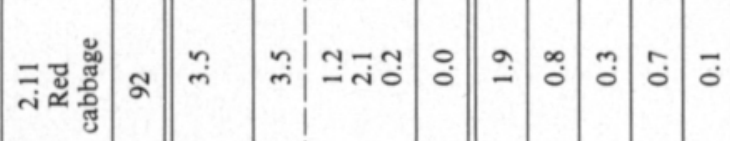

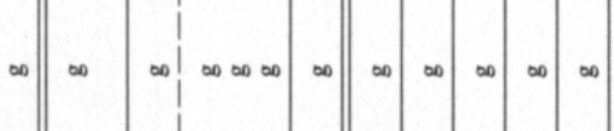

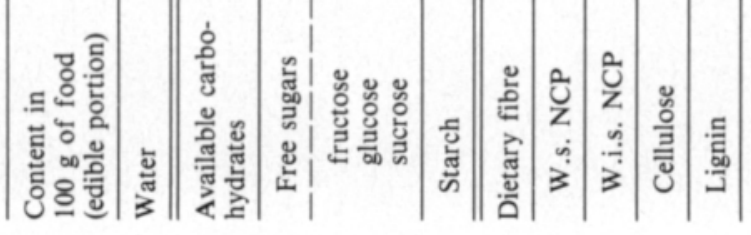




\begin{tabular}{|c|c|c|c|c|c|c|c|c|c|c|}
\hline 只 ํㅡㄹ & $\infty$ & $\stackrel{0}{\infty}$ & $\frac{9}{r}$ & $\because \bar{i} \stackrel{m}{-}$ & $\overline{0}$ & $\stackrel{\infty}{-}$ & $\hat{0}$ & : & $\stackrel{0}{0}$ & $\overline{0}$ \\
\hline సి & $\approx$ & $\tilde{0}$ & $\tilde{o}$ & mํํํำ & $\stackrel{0}{0}$ & $\stackrel{+}{-}$ & $\tilde{o}$ & ั๋ & $\stackrel{+}{0}$ & $\overline{0}$ \\
\hline 文 & ส & $\tilde{i}$ & $\tilde{n}$ & 导こ & $\stackrel{0}{0}$ & $\stackrel{\circ}{i}$ & $\stackrel{\circ}{\circ}$ & ¿̊ & oे & $\overrightarrow{0}$ \\
\hline 究 & 2 & $\stackrel{\square}{-}$ & $\stackrel{+}{-}$ & $\hat{0}$ & $\stackrel{\circ}{\circ}$ & $\Xi$ & ¿̊. & o & $\tilde{0}$ & $\overline{0}$ \\
\hline 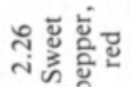 & $\bar{\sigma}$ & $\stackrel{n}{\sim}$ & $\stackrel{\sim}{\sim}$ & तें & $\stackrel{\circ}{\circ}$ & 9 & ò & i & $\ddot{0}$ & กั \\
\hline 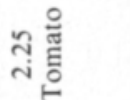 & ヌ & $\stackrel{+}{r}$ & $\stackrel{m}{m}$ & 을 & $\overline{0}$ & $\stackrel{ \pm}{-}$ & $\stackrel{\circ}{\circ}$ & ஸั & ப் & ஸั \\
\hline 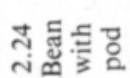 & \& & $\stackrel{\sim}{+}$ & $\stackrel{\vec{i}}{\mathrm{i}}$ & $\ddot{0}$ & $\stackrel{\infty}{-}$ & $\stackrel{\vec{i}}{\mathrm{i}}$ & gे & $\dddot{n}$ & ڤे & $\overline{0}$ \\
\hline సి తే & $\stackrel{\circ}{\sim}$ & $\tilde{n}$ & $\stackrel{\circ}{+}$ & 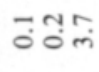 & $\Xi$ & $\tilde{n}$ & $\dddot{n}$ & กี & $\hat{i}$ & $\overrightarrow{0}$ \\
\hline તู่ & $\infty$ & $\Xi$ & $\stackrel{\infty}{0}$ & mon & ?. & ì & $\stackrel{\infty}{\circ}$ & $\tilde{0}$ & $\dddot{m}$ & ? \\
\hline & $\infty$ & $\infty$ & $\infty$ & $\infty \infty \infty \infty$ & $\infty$ & $\infty$ & $\infty$ & $\infty$ & $\infty$ & $\infty$ \\
\hline 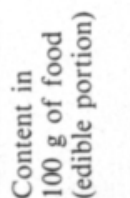 & 岕 & 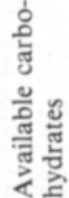 & 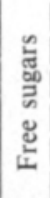 & 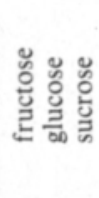 & 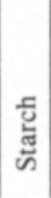 & 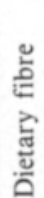 & $\begin{array}{l}\vec{u} \\
z \\
\dot{n} \\
\dot{3}\end{array}$ & 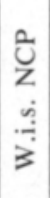 & $\frac{\mathscr{0}}{\mathrm{\Xi}}$ & . \\
\hline
\end{tabular}




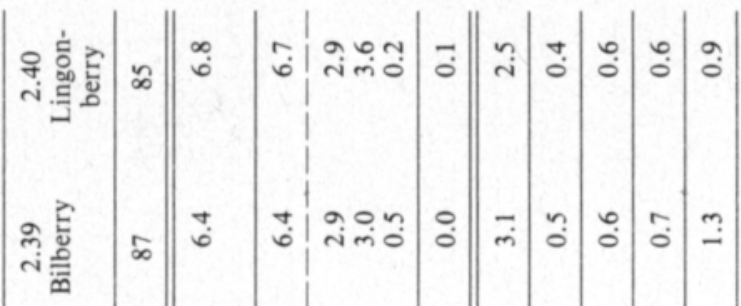

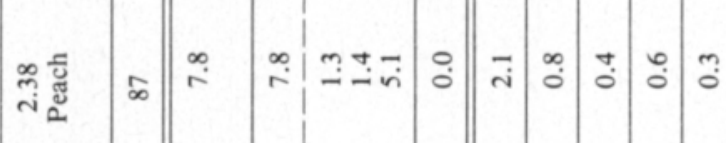

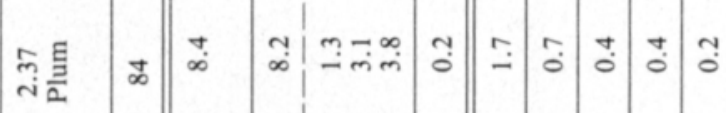

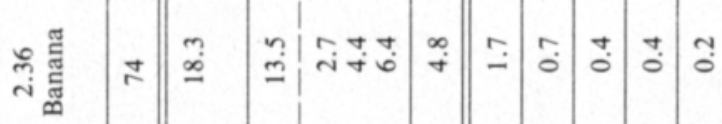

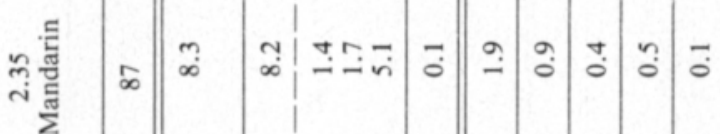

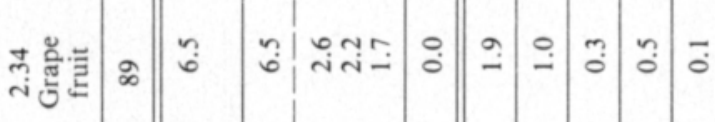

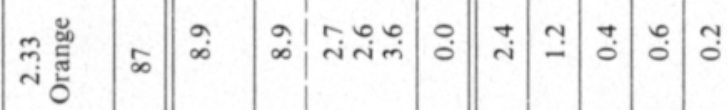

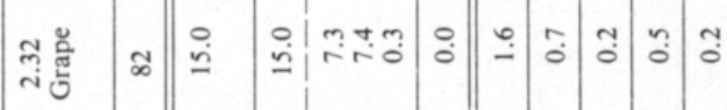

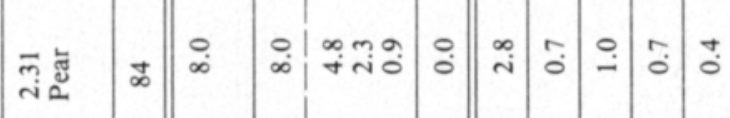

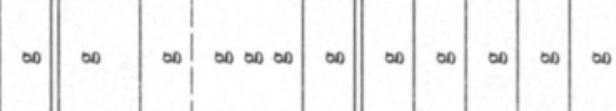

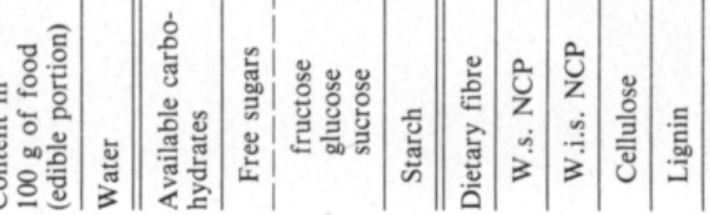




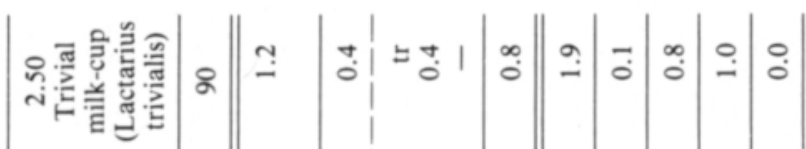

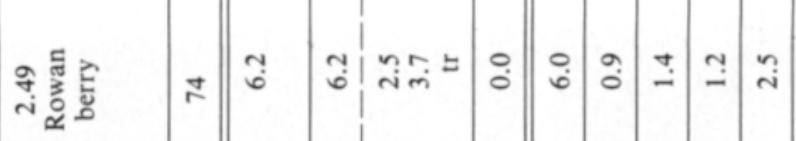

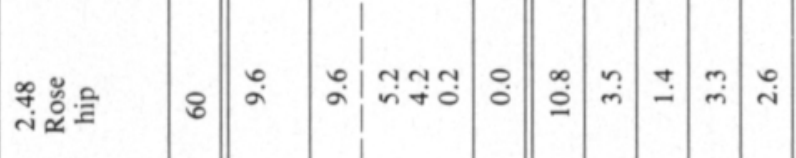

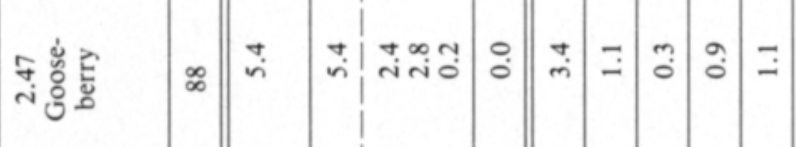

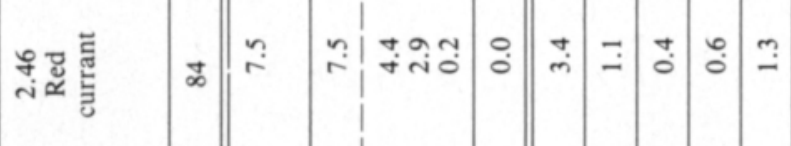

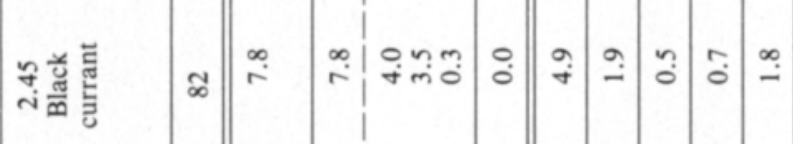

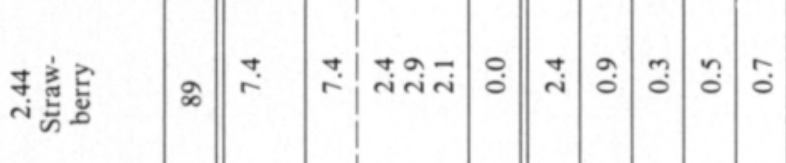

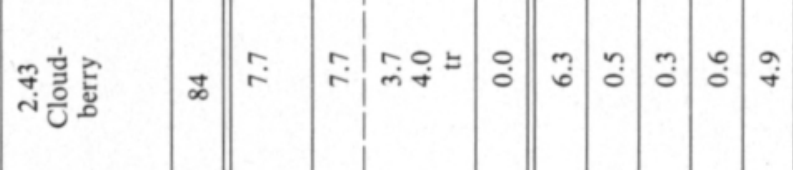

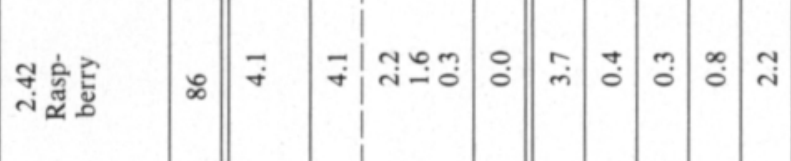

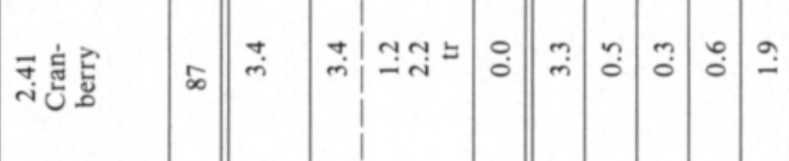

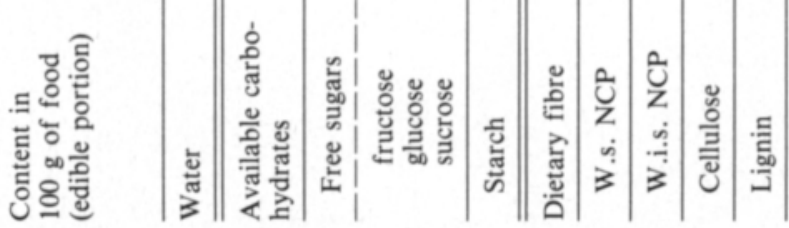




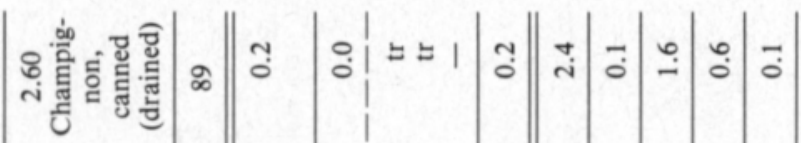

$$
\begin{aligned}
& \text { कิ }
\end{aligned}
$$

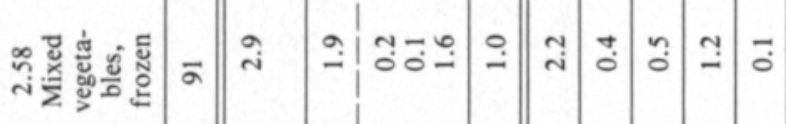

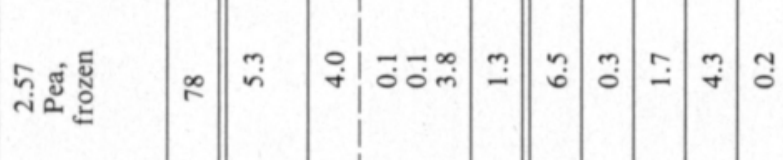

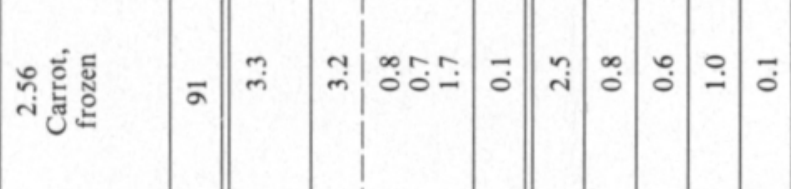

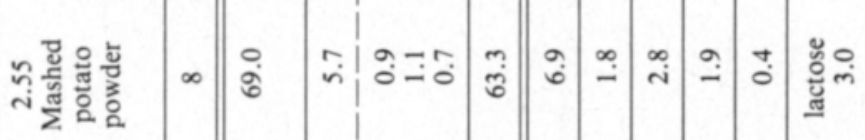

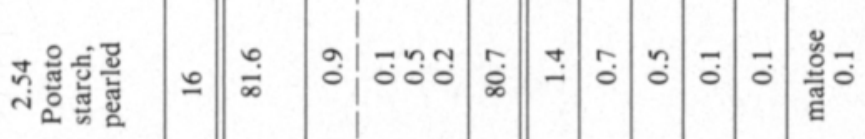

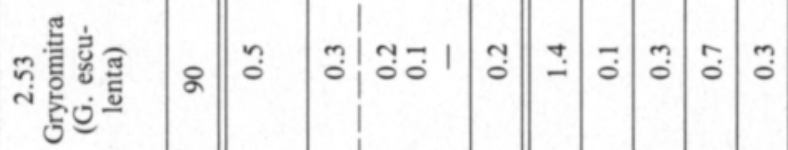




\begin{tabular}{|c|c|c|c|c|c|c|c|c|c|c|}
\hline 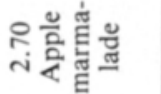 & F & $\stackrel{9}{\dot{j}}$ & j & 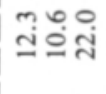 & $\because$ & aे & $\dddot{n}$ & ஸี & ஸี & $\stackrel{\circ}{\circ}$ \\
\hline 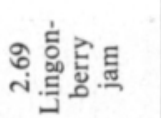 & i & $\stackrel{\sim}{m}$ & $\stackrel{n}{q}$ & 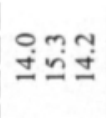 & $\stackrel{\circ}{\circ}$ & $\dddot{n}$ & ¿े & ? & ¿ே & $\stackrel{0}{0}$ \\
\hline 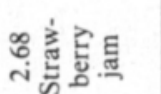 & ஜ & 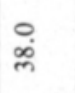 & $\stackrel{n}{m}$ & กุழ & $\dddot{n}$ & $?$ & $\stackrel{\bullet}{\circ}$ & กั & : & $\overline{0}$ \\
\hline 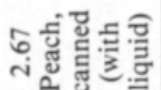 & 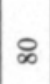 & $\stackrel{\text { בุ }}{\varrho}$ & 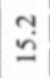 & 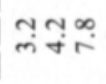 & $\stackrel{\circ}{\circ}$ & $\stackrel{\infty}{\circ}$ & ? & ஸั & ஸุ & $\overline{0}$ \\
\hline 范 & ్ㅗ & $\stackrel{m}{i}$ & $\stackrel{m}{i}$ & तెंबें & $\because$ & $\stackrel{\circ}{\circ}$ & $\stackrel{\circ}{-}$ & 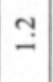 & $\stackrel{m}{-}$ & $\stackrel{n}{n}$ \\
\hline 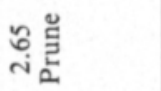 & A & 品 & $\underset{m}{\infty}$ & $\begin{array}{l}0 \\
\dot{u} \\
\dot{u}\end{array}$ & $\stackrel{0}{\circ}$ & $\stackrel{r}{r}$ & $\tilde{n}$ & $\stackrel{+}{-}$ & $\stackrel{\infty}{i}$ & $\stackrel{\circ}{i}$ \\
\hline 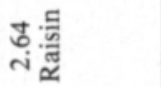 & ป & $\overrightarrow{8}$ & $\overline{8}$ & केసั & $\stackrel{0}{\circ}$ & a. & $\dddot{n}$ & I & $\stackrel{m}{i}$ & $\stackrel{N}{N}$ \\
\hline io & \% & $\overrightarrow{0}$ & $\overrightarrow{0}$ & $= \pm \frac{0}{0}$ & $\ddot{0}$ & I & $\stackrel{+}{0}$ & ¿̊ & $\stackrel{\infty}{0}$ & $\overline{0}$ \\
\hline 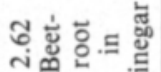 & $\infty$ & $\hat{b}$ & $\hat{b}$ & 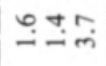 & $\stackrel{\circ}{\circ}$ & $\stackrel{\infty}{-}$ & $\dddot{n}$ & : & $\stackrel{\infty}{\circ}$ & $\overline{0}$ \\
\hline 范范 & $\approx$ & $\stackrel{\circ}{r}$ & $\stackrel{\circ}{\dot{m}}$ & 웅요 & $\stackrel{\circ}{\circ}$ & $\stackrel{\infty}{-}$ & $\stackrel{b}{0}$ & $\tilde{c}$ & $\stackrel{0}{\circ}$ & $\overline{0}$ \\
\hline & $\infty$ & $\infty$ & $\infty$ & 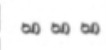 & $\infty$ & $\infty$ & $\infty$ & $\infty$ & $\infty$ & $\infty$ \\
\hline 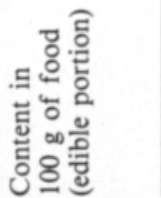 & 岕 & 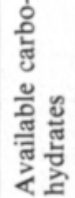 & 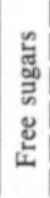 & 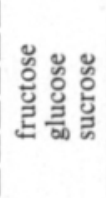 & 竎 & 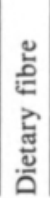 & $\begin{array}{l}\text { 仓ि } \\
z \\
\dot{n} \\
\dot{3}\end{array}$ & 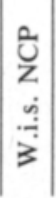 & $\begin{array}{l}\text { 을 } \\
\text { 光 }\end{array}$ & 믈 \\
\hline
\end{tabular}


reflection of the complexity of the analytical procedure, which allowed only a very limited number of samples to be analysed within the context of the present study.

The analytical scheme used was that developed by ENGLYST (1981) and slightly modified by LAINE et al. (1981). The method has been described in detail in the preceding paper (VARO et al. 1984). The standard sample was the same as in the cereal study. For comparison, the total dietary fibre of some vegetables and fruits was also analysed with the enzymatic-gravimetric method of Asp et al. (1983). This showed that the results obtained with the present method were 10-15\% lower than those obtained with the enzymaticgravimetric analysis in this category of foods (VARO 1984).

The results of the water-soluble non-cellulosic polysaccharide (w.s. NCP) fraction tended to be the most variable, and the whole fraction was therefore completely re-analysed on a sample 10 times bigger using gravimetric determination of filtered and dried precipitate. Free sugars and, less often, lignin caused rechecks.

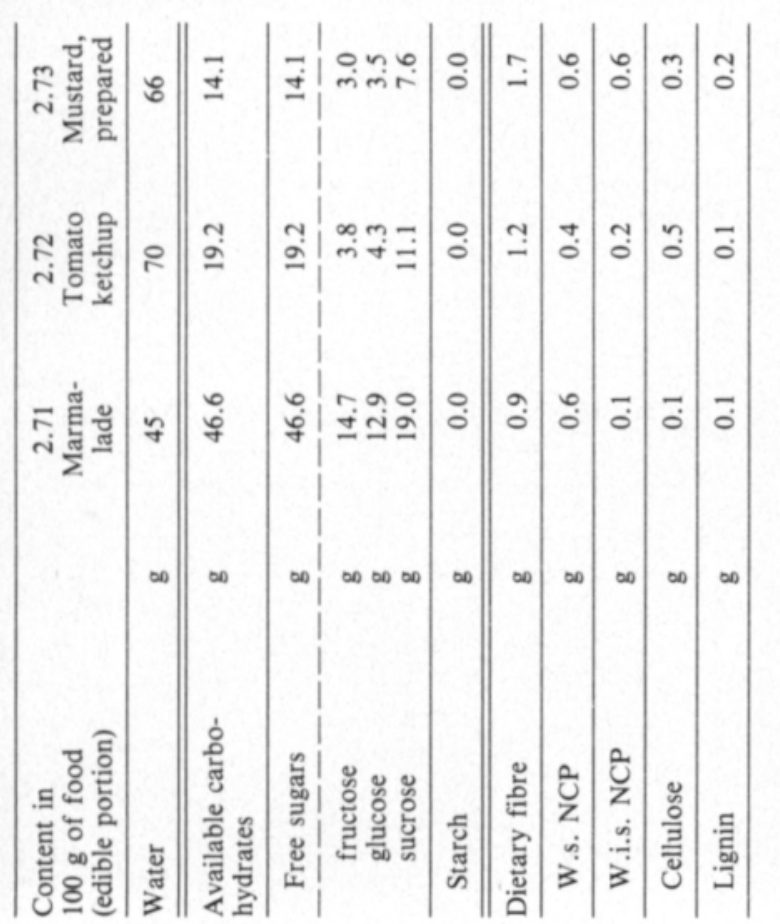

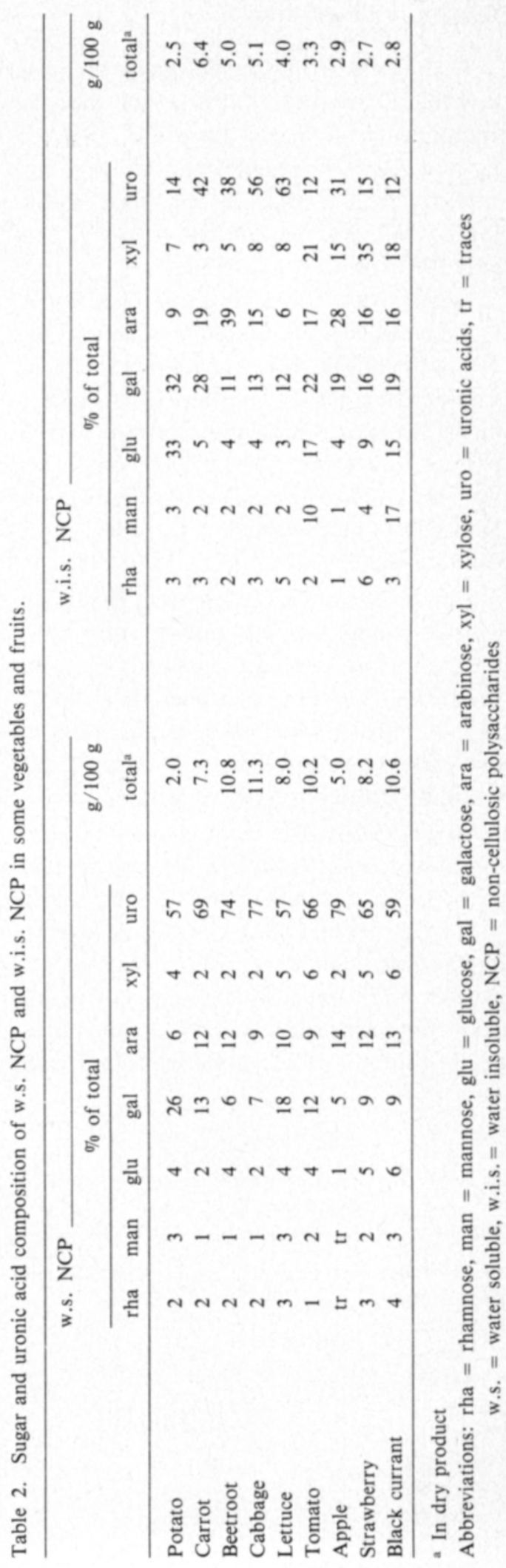




\section{Results and discussion}

The results of the present study are given in Table 1. Free sugars, starch and the main components of dietary fibre are tabulated. By and large, the results are consistent with findings from earlier carbohydrate studies (Salo 1967, Paul \& Southgate 1979, EngLYST 1981, Soucl et al. 1981).

Sugars. Most vegetables, fruits and berries contain considerable amounts of natural sugars. Usually the three sugars glucose, fructose and sucrose are present, fructose often being the most abundant. Sorbitol may be present, too (Soucl et al. 1981), but it was not measured in the present study. Canned fruits, jams and marmalades contain appreciable added sugar.

Starch. The amount of starch, if present, is usually quite low. Its concentration is distinctly highest in potato and banana. Some vegetables contain fructosanes (SALO 1967). In this study they were detected in onion. In the present analytical scheme these carbohydrates were cohydrolysed with starch.

Dietary fibre. The fibre content of vegetables and fruits is high in relation to their energy content. It was highest in some berries with seeds, which increase the lignin fraction in particular. The water-soluble fraction was usually quite large. The sugar and uronic acid composition of w.s. NCP and w.i.s. $\mathrm{NCP}$ of some vegetables and fruits is given in
Table 2. Uronic acids were the main constituents of the w.s. NCP fraction; the composition of w.i.s. NCP was more variable and included large amounts of galactose, pentoses and uronic acids.

According to statistics (ANON. 1981, Agric. Econ. Res. Inst. 1983), the average consumption of vegetables in 1981 was $116 \mathrm{~g} / \mathrm{d}$ and that of fruits $239 \mathrm{~g} / \mathrm{d}$. The average consumption of potato was $162 \mathrm{~g} / \mathrm{d}$. The vegetables with the highest consumption are cucumber, tomato, cabbage and carrots, their share being over $60 \%$ of the total. Citrus fruits, apples and banana are the principal fruits, their share being nearly $70 \%$ of total fruit consumption. The most common processed products are various juices, especially orange juice. The estimate of the daily intakes of sugars and fibre given in Table 3 is based on these statistics. The estimated fibre intake from cereals was $11.6 \mathrm{~g} / \mathrm{d}$ (VARo et al. 1984). Thus, the total fibre intake is $19 \mathrm{~g} / \mathrm{d}$. This is well within the range of other estimates of the average fibre intake in Finland (LAAKKONEN \& HAARAMO 1983). It was also calculated that added sugar accounts for about $20 \%$ of the total intake of soluble sugars received from this category of foods.

Acknowledgement. This study was supported by the Academy of Finland and the Finnish Sugar Company Ltd.

Table 3. The estimated average intake $(\mathrm{g} / \mathrm{d})$ of dietary fibre and available carbohydrates derived from vegetables and fruits (energy level $10 \mathrm{MJ}$ ).

\begin{tabular}{lcccr}
\hline & Vegetables & Fruits & Potato & Total \\
\hline Total sugars & 3.3 & 19.3 & 1.1 & 23.7 \\
$\quad$ fructose & 1.2 & 7.3 & 0.4 & 8.9 \\
glucose & 1.2 & 5.9 & 0.4 & 7.5 \\
sucrose & 0.9 & 6.1 & 0.3 & 7.3 \\
Starch & 0.2 & 0.6 & 29.8 & 30.6 \\
Dietary fibre & 1.8 & 3.3 & 2.1 & 7.2 \\
w.s. NCP & 0.6 & 1.3 & 0.6 & 2.5 \\
w.i.s. NCP & 0.3 & 0.6 & 0.7 & 1.6 \\
cellulose & 0.7 & 0.8 & 0.6 & 2.1 \\
lignin & 0.2 & 0.6 & 0.2 & 1.0 \\
\hline
\end{tabular}




\section{References}

Agricultural Economics Research Institute, 1983. Food balance sheet 1981. Helsinki.

ANON. 1981. Vihannesten kulutus. Puutarhauutiset No. 47,1112 .

Asp, N.-G., Johansson, C.-G., Hallmer, H. \& Siljestróm, M. 1983. Rapid enzymatic assay of insoluble and soluble dietary fiber. J. Agric. Food Chem. 31: 476 -482 .

Eastwood, M.A. 1983. Physical properties of fibre towards bile acids, water and minerals. In: Dietary Fibre (Eds. G.G. Birch \& K.J. PARKer), p. 149-164. Applied Science Publishers, London.

ENGLYST, H. 1981. Determination of carbohydrate and its composition in plant materials. In: The Analysis of Dietary Fiber in Food (Eds. W.P.T. James \& O. TheANDER), p. 71-93. Marcel Dekker, N.Y.

LAaKKonen, E. \& HaARAmo, A.-M. 1983. Ravintokuidun saannin kehitys 1900-luvulla. Elintarvikkeiden Tutkimussaaătiô, Julkaisu No. 13: 86-103.

Laine, R., VAro, P. \& Koivistoinen, P. 1981. Observa- tions on the analysis of dietary fiber. In: The Analysis of Dietary Fiber in Food (Eds. W.P.T. JAMEs \& O. TheANDER), p. 21-27. Marcel Dekker, N.Y.

Paul, A.A. \& Southgate, D.A.T. 1979. McCance and Widdowson's the Composition of Foods, 4th ed. HMSO, London.

SALO, M.-L. 1967. Carbohydrates of some vegetables. Acta Agric. Fenn. 109, 1: 101-104.

Souci, S.W., Fachmann, W. \& Kraut, H. 1981. Food Composition and Nutrition Tables 1981/82. Wissenschaftliche Verlagsgesellschaft, Stuttgart.

VARO, P. 1984. Suomalaisten elintarvikkeiden ravintokuitututkimus. Elintarvikeylioppilas No. 2: 24-27.

Varo, P., Laine, R., Veijalainen, K., Pero, K. \& Koivis. TOINEN, P. 1984. Dietary fiber and available carbohydrates in Finnish cereal products. J. Scient. Agric. Soc. Finl.

Ms received January 30, 1984

\section{SELOSTUS}

\section{Suomalaisten elintarvikkeiden hiilihydraatti- tutkimus - kasvisten, hedelmien ja marjojen ravintokuitu-, tärkkelys- ja sokeripitoisuudet}

\section{Pertti Varo, Raili Laine, Kirsti Veijalainen, Aila Espo, Anne Wetterhoff ja \\ Pekka Koivistoinen \\ Elintarvikekemian ja -teknologian laitos, \\ Helsingin yliopisto, $00710 \mathrm{Helsinki}$}

Tăssă tutkimuksessa maaăritettiin meillă kulutuksen kannalta tărkeimpien kasvisten, hedelmien ja marjojen sekă niistä saatavien valmisteiden hiilihydraattikoostumus. Analyyttisenă menetelmănă kăytettiin ns. Englystin kokonaishiilihydraattimenetelmää. Julkaisussa on taulukoitu tiedot 73 elintarvikenimikkeen hyväksikäytettåvien hiilihydraattien ja ravintokuidun määrästä ja laadusta. Tutkimus on osa poikkileikkaustutkimusta, jonka tavoitteena on saada yleiskuva suomalaisten elintarvikkeiden hiilihydraattikoostumuksesta. Saatujen tulosten ja kulutustietojen perusteella arvioitiin hiilihydraattien keskimaaărăinen păivăsaanti kasvisryhmăn elintarvikkeista. Saantiarvot olivat: liukoisia sokereita yhteensä $23.7 \mathrm{~g}$, tărkkelystä $30.6 \mathrm{~g}$ ja ravintokuitua $7.2 \mathrm{~g}$ (energiataso $10 \mathrm{MJ}$ ). 